\title{
Biometry in Umbu fruits from the semi-arid region of Paraiba
}

\author{
Fábio Rodrigo Araújo Pereira ${ }^{1}$, Walter Esfrain Pereira ${ }^{2}$, Angela Maria dos Santos Pessoa ${ }^{3}$, \\ Erika Socorro Alves Graciano de Vasconcelos ${ }^{4}$
}

\begin{abstract}
Umbu fruits from four municipalities of Paraíba were morphologically characterized in order to identify promising genotypes for fresh consumption and agro-industrial use. We used 400 fruits from parent plants located in São Vicente do Seridó, Queimadas, Boqueirão, and Cabaceiras and 40 commercial fruits from two open fairs in Campina Grande, PB. The experimental unit consisted of ten fruits. The fruits were analyzed for total mass (MTF), length (LC), diameter (DF), fresh matter (MMF), yield (RF), and presence of hairs. In the endocarps, mass (ME), length (CE), diameter (DE), and width (LE) were the evaluated parameters. A completely randomized design was adopted, the data were subjected to variance analysis, and the means were compared by the Tukey test and principal component analysis. The fruits from Queimadas and São Vicente do Seridó showed the best morphological characters with regard to mass, length, diameter, fresh matter, and fruit yield, and were the most promising for agro-industrial commercialization. The fruits from Boqueirão showed the highest endocarp mass. Most fruits showed hairs on the peel, except the commercial ones. Four groups of municipalities were formed, with the fruits from Queimadas showing the largest size, while the fruits from São Vicente de Seridó and Soledade showed the highest yield.
\end{abstract}

Index terms: Anacardiaceae. Caatinga. Morphological characterization. Spondias tuberosa Arr. Camara.

Corresponding author: fabiorodrigopereira@hotmail. com

\section{Received: May 14, 2021}

Accepted: August 18, 2021

Copyright: All the contents of this journal, except where otherwise noted, is licensed under a Creative Commons Attribution License.

\section{(cc) $\mathbf{E Y}$}

\section{Biometria em frutos de umbuzeiros provenientes do semiárido Paraibano}

Resumo- Foram caracterizados morfologicamente umbus de quatro municípios paraibanos a fim de identificar genótipos promissores para consumo in natura e emprego agroindustrial. Foram utilizados 400 frutos de matrizes de São Vicente do Seridó; Queimadas; Boqueirão e Cabaceiras, e 40 frutos comerciais de duas feiras de Campina Grande-PB. A unidade experimental foi constituída por 10 frutos. Foram analisados nos frutos: massa total (MTF); comprimento (CF); diâmetro (DF); matéria fresca (MMF), rendimento (RF) e presença de pelos. Nos endocarpos, foram avaliados massa (ME); o comprimento (CE), o diâmetro (DE) e a largura (LE). Foi adotado o delineamento inteiramente casualizado, e os dados foram submetidos à análise de variância, com as médias comparadas pelo teste de Tukey, assim como a análise de componentes principais. Os frutos de Queimadas e São Vicente do Seridó apresentaram melhores caracteres morfológicos quanto à massa, ao comprimento, ao diâmetro, à matéria fresca e ao rendimento dos frutos, sendo mais promissores para comercialização agroindustrial. Já os frutos provenientes de Boqueirão apresentaram maior massa de endocarpo. A maioria dos frutos apresentou pelos nas cascas, exceto os comerciais. Foram formados quatro grupos de municípios, sendo os frutos provenientes de Queimadas os que apresentaram maior tamanho, enquanto os frutos provenientes de São Vicente do Seridó e de Soledade apresentaram maior rendimento.

Termos para indexação: Anacardiaceae. Caatinga. Caracterização morfológica. Spondias tuberosa Arr. Camara. 


\section{Introduction}

Fruit farming is one of the main segments of Brazilian agriculture, directly competing with the international market every year (IBRAF, 2017). Brazil currently occupies the third position among fruitproducing countries, second only to China and India (CARVALHO et al., 2019). According to FAO (2010), fruit intake is an important element of the human diet, and daily fruit consumption is recommended as a mechanism to prevent diseases and improve health (TAVARES et al., 2020; LIMA JUNIOR et al., 2020).

Northeastern Brazil has a high number of nutritionally important native fruit species, especially for the local populations of this semi-arid region (TEXEIRA et al., 2019). One such species, umbu (Spondias tuberosa Arruda Camara) belongs to the family Anacardiaceae and has the potential for agro-industrial use (LIMA et al., 2015). This plant is endemic to the Caatinga. Its fruits are commonly known as umbu, imbu, ambu, taperebá, or cajádo-sertão and have a globose or ovoid shape. They also have a sweet, juicy, and fibrous pulp rich in antioxidants and with a bittersweet taste (carotenoids, vitamin C, and phenolic compounds), contributing to controlling free radicals and preventing aging and diseases such as cancer, rheumatoid arthritis, Parkinson's disease, and Alzheimer's disease, in addition to showing antimicrobial activity (LORENZI et al., 2015; RIBEIRO et al., 2017; ASSIS et al., 2020; ALCÂNTARA et al., 2021).

Umbu fruits are sold by small producers in open fairs, streets, and sidewalks and can be consumed fresh or used to prepare beverages, ice cream, or 'umbuzadas' (umbu pulp cooked with milk and sugar) (SILVA et al., 2018; CONCEIÇÃO et al., 2020; PÁDUA et al., 2020; CORDEIRO et al., 2020). Their use in the food industry consists of manufacturing by-products such as frozen pulps, nectar, and liqueurs. Umbu is also used for human and animal feeding, the latter through the supply of leaves and fruits for goats and sheep in the rainy and dry periods (GOMES et al., 2018; SENA; ALMEIDA, 2020).

This highlights the essential role that umbu plays in the region as it represents an alternative source of food and income for small producers, especially during drought periods in the Northeast region (ARAÚJO et al., 2020). Moreover, the species has the environmental potential to form commercial orchards and to recover deforested areas in the Caatinga.

Seasonal umbu production occurs in the rainy period, from December to June (ALVES et al., 2020; BATISTA et al., 2015), varying according to the region and rainfall distribution as well as the types of soil and genotypes.
Although the exploitation of umbu trees has grown steadily due to the several uses of the species, there are still few assessment studies on its quality and genotypic potential in the regions of the state of Paraíba with the capability of stimulating the formation of orchards by producers or fostering local investment for the appropriate exploitation of plants and application of important technological methods for production, harvest, and use of good fruits (MARQUES; FREITAS, 2020), thus contributing to the commercial exploitation and domestication of Spondias tuberosa, as stressed by Matos et al. (2020). Such investments could contribute to elevating Paraíba from a minor producer status to a production level close to that of Bahia, the leading umbu producer in the country.

The biometric characterization of fruits, endocarps, and seeds has been an important instrument used in fruit farming to obtain ecological data from plant groups from different geographic regions where the environment can influence phenotypes (CONCEIÇÃO; BARROS, 2020). According to Souza and Cavalcante (2019) and Araújo et al. (2014), this technique allows determining the genetic variations in populations of the same species and evaluating the relationship of environmental factors with these variations observed in the individuals.

From this perspective, the characterization of umbu accessions with regard to their fruits and endocarps contributes to subsidizing the identification of genotypes and their genetic variability, in addition to determining cultivars with the potential for immediate use by producers and defining which genotypes have desirable characteristics for the genetic improvement of the species and associated studies (FRANÇA et al., 2019; SANTOS; ALMEIDA, 2019; CONCEIÇÃO; BARROS, 2020; SANTOS et al., 2020).

Therefore, this study aimed to morphologically characterize umbu fruits from four municipalities in the semi-arid region of Paraíba in order to identify promising genotypes for fresh consumption and agro-industrial use.

\section{Material and methods}

This study was conducted from March to May 2020 and used 440 umbu fruits (Spondia tuberosa Arr. Câmara), 400 of which came from parent plants from four municipalities in the state of Paraíba: São Vicente do Seridó (SVS), Queimadas (Q), Boqueirão (B), and Cabaceiras (C), with 100 fruits from each location and 20 units per plant, in addition to 40 commercial fruits $(\mathrm{A}=$ Arca Titão and $\mathrm{B}=$ Arca Catedral) obtained from open fairs in Campina Grande, PB. The experimental unit, corresponding to the set of analyzed fruit samples, was formed by ten fruits.

Table 1 shows the climate and location data of the municipalities. 
Table 1. Geographic location of the municipalities of Paraíba.

\begin{tabular}{cccccccc}
\hline & \multicolumn{3}{c}{ Location } & & Climate & $\begin{array}{c}\text { Mean annual } \\
\text { temperature }\left({ }^{\circ} \mathrm{C}\right)\end{array}$ & $\begin{array}{c}\text { Rainfall } \\
(\mathrm{mm} / \text { year })\end{array}$ \\
\cline { 2 - 4 } Municipality & Latitude & Longitude & $\begin{array}{c}\text { Elevation } \\
(\mathrm{m})\end{array}$ & & Semi-arid & 23.3 & 469.3 \\
São Vicente do Seridó & -6.9356 & -36.3772 & 631 & & Semi-arid & 23.3 & 478.5 \\
Queimadas & -7.3580 & -35.9019 & 450 & & Tropical & 23.7 & 351.6 \\
Boqueirão & -7.4908 & -36.1358 & 355 & & Semi-arid & 23.4 & 332.3 \\
Cabaceiras & -7.4922 & -36.2869 & 388 & &
\end{tabular}

Source: Aesa/PB (2020); Francisco and Santos (2017;2018); Francisco et al. (2016).

The plant material was harvested directly from the trees by visually selecting the ripe fruits (considering a greenish-yellow peel color), always in the morning. Subsequently, the material was placed in a thermal box and taken for analysis at the Laboratory of Food Technology of the Maurício de Nassau Faculty/Campina Grande (PB) for fruit characterization using the following parameters: total mass (MTF), length (CF), diameter (DF), fresh matter (MFF), and yield (RF). The endocarps were analyzed for their mass (ME), length (CE), diameter (DE), and width (LE). Total fruit mass (fresh matter and endocarp) and endocarp mass were measured using a semi-analytical balance, with values expressed in grams (g). Fresh fruit mass (epicarp and mesocarp) was determined by the difference between fruit mass and endocarp mass.

Fruit yield, expressed as percentages, was obtained by the ratio between MFF and MTF multiplied by 100 (MENEZES et al., 2017). Length, diameter, and width were measured with a digital caliper (ZAAS Precision ${ }^{\circledR}$ ) in millimeters. The fruits were also analyzed for the presence or absence of hairs.

A completely randomized experimental design was adopted for data evaluation, and the data obtained were subjected to analysis of variance, while the means were compared by the Tukey test at $5 \%$ probability. The data were also subjected to principal component analysis (HUSSON et al., 2017) based on the correlation matrix, with the extraction of the associated eigenvectors and eigenvalues and cluster formation. The software R, version 4.0, was used for the statistical analyses.

\section{Results and discussion}

The mean total mass of umbu fruits was approximately $21 \mathrm{~g}$, varying from 19.8 to $23.0 \mathrm{~g}$ (Table 2 ), with the fruits from Queimadas being the heaviest. The mean value (MTF) obtained in this study was similar to that found by Costa et al. (2015) but higher than that of Santos (1997), who found a mean fruit mass of umbu fruits of $18.4 \mathrm{~g}$. These results were also higher than those obtained by Alves et al. (2020) in their study on the postharvest quality of umbu fruits from Santana do Ipanema/ $\mathrm{AL}$, with $15.38 \mathrm{~g}$. The variation found in these studies may be related to the characteristic physiological maturation (late or early) and fruit growth of each genotype, the period between fruit harvest and evaluation, and the edaphoclimatic conditions, such as the annual rainfall rate (as verified in Figure), soil characteristics, and the local temperature of each location.

Table 2. Mean total mass (MTF), length (CF), diameter (DF), fresh mass (MFF), and yield (RF) of fruits of Spondias tuberosa from semi-arid regions of Paraíba.

\begin{tabular}{cccccc}
\hline Municipality & MTF $(\mathrm{g})$ & $\mathrm{CF}(\mathrm{mm})$ & $\mathrm{DF}(\mathrm{mm})$ & $\mathrm{MFF}(\mathrm{g})$ & $\mathrm{RF}(\%)$ \\
\hline Boqueirão & $20.5 \mathrm{~b}$ & $34.2 \mathrm{~b}$ & $31.4 \mathrm{~b}$ & $18.7 \mathrm{~b}$ & $91.23 \mathrm{~b}$ \\
Cabaceiras & $19.8 \mathrm{~b}$ & $33.9 \mathrm{~b}$ & $31.2 \mathrm{~b}$ & $18.3 \mathrm{~b}$ & $91.83 \mathrm{~b}$ \\
Queimadas & $23.0 \mathrm{a}$ & $36.2 \mathrm{a}$ & $33.0 \mathrm{a}$ & $21.5 \mathrm{a}$ & $93.28 \mathrm{a}$ \\
São Vicente do Seridó & $20.6 \mathrm{~b}$ & $34.9 \mathrm{ab}$ & $31.5 \mathrm{~b}$ & $19.2 \mathrm{~b}$ & $93.17 \mathrm{a}$ \\
Commercial A & $14.9 \mathrm{c}$ & $31.2 \mathrm{c}$ & $28.9 \mathrm{c}$ & $13.7 \mathrm{c}$ & $91.69 \mathrm{~b}$ \\
Commercial B & $19.2 \mathrm{~b}$ & $33.8 \mathrm{bc}$ & $30.6 \mathrm{bc}$ & $18.1 \mathrm{~b}$ & $94.00 \mathrm{a}$ \\
C.V\% & 20.2 & 8.8 & 8.6 & 20.9 & 2.2 \\
\hline
\end{tabular}

Means followed by the same letters in the columns do not differ by the Tukey test at $5 \%$ probability. Commercial 'A' = Fuits from Pocinhos (PB), sold at the Arca Titão fair/Downtown Campina Grande. Commercial 'B' = Fruits from Soledade (PB), sold at the Arca Catedral fair/ Downtown Campina Grande. 


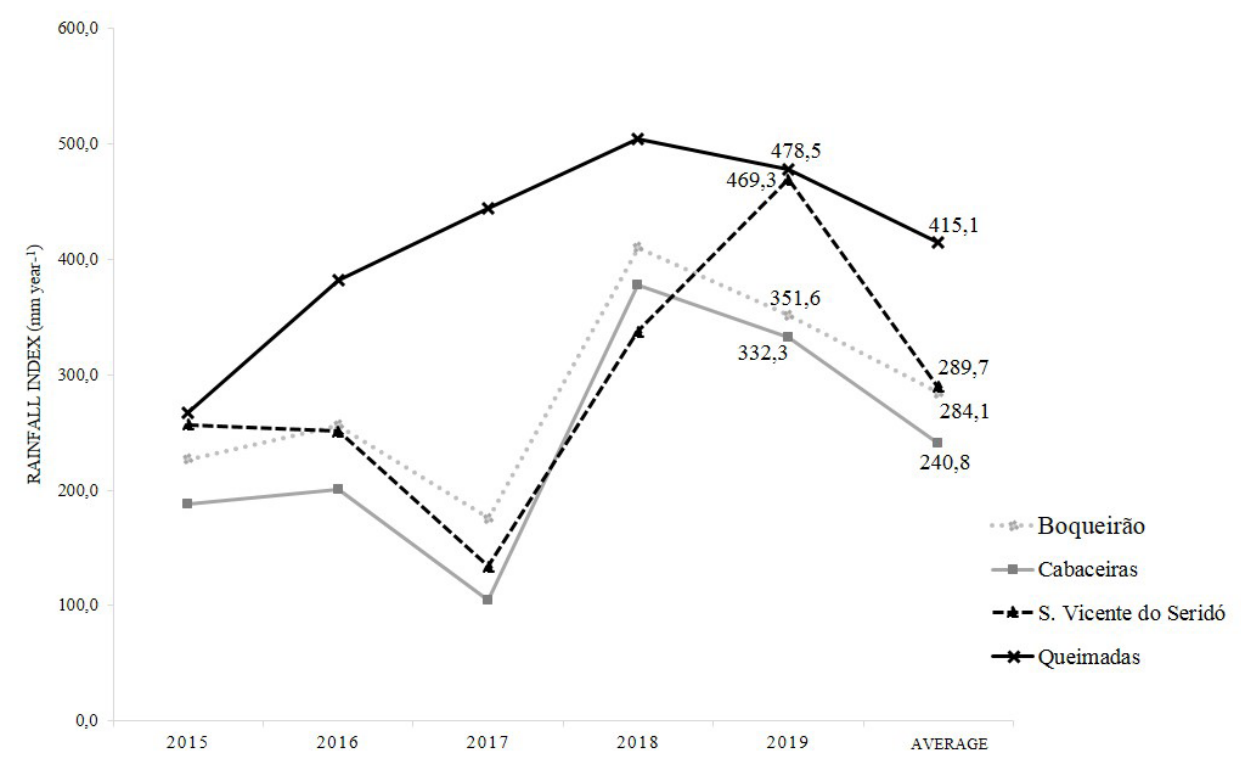

Figure 1. Annual rainfall rates of the four municipalities in the semi-arid region of Paraíba with parent umbu plants used for the biometric evaluation of fruits (Data from 2015 to 2019 - Adapted from AESA/PB).

Despite these mean values, there is no clear standard with regard to the mass of umbu fruits meant for sale. When comparing the mean fruit mass from each region with the mass of fruits traded at the two central fairs of Campina Grande/PB, the accessions from the four municipalities showed superior results compared to the commercial fruits ' $A$ '. On the other hand, the total fruit mass from Boqueirão, Cabaceiras, and São Vicente do Seridó showed similar behaviors to commercial fruits ' $\mathrm{B}$,' suggesting the possible viability of the parent plants analyzed for commercial exploitation, especially for the agro-industrial market, which prefers ripe fruits, with higher masses, larger sizes (CASTRO; RYBKA, 2015), and selected by pickers.

With regard to fruit length and diameter, the units from Queimadas were also those with the highest values (36.2 $\mathrm{mm}$ and $33 \mathrm{~mm}$, respectively) compared to those from other municipalities (Table 2). However, for these parameters ( $\mathrm{CF}$ and $\mathrm{DF}$ ), the mean values for all regions agreed with those in the literature, with fruit length varying from $26 \mathrm{~mm}$ to $60 \mathrm{~mm}$ and fruit diameter varying from 23 $\mathrm{mm}$ to $60 \mathrm{~mm}$ (COSTA et al., 2015; DUTRA et al., 2017; SILVA et al., 2019). Compared to the CF and DF values of the commercial units, the genotypes from São Vicente do Seridó (SSV), Queimadas (Q), Boqueirão (B), and Cabaceiras (C) showed higher values for these parameters, as well as those studied by Menezes et al. (2017) in their study on the maturation stage and physicochemical quality of umbu fruits in the municipality of São José de Espinharas, Paraíba.

Both length and diameter are highly useful biometric parameters when fruits are meant for the fresh consumption market as they influence consumer acceptance, who prefer large fruits.
When analyzing the fresh matter (MFF) of umbu fruits by considering the peel and pulp, the fruits from Queimadas also showed the highest mean (21.5 g), above the regional mean value for this variable (Table 2). This factor is important since, for umbu fruits, peel and pulp are the parts used to produce juices, pulps, sweets, and 'umbuzada,' among other by-products (RIBEIRO et al., 2017; PAODJUENAS et al., 2019; CASTRO; RYBKA, 2020).

For fruit yield, similar means were obtained for the units from Queimadas, São Vicente do Seridó, and commercial fruits ' $\mathrm{B}$ ' (Table 2). This demonstrates that the fruits from Queimadas are the most promising for commercial use, especially for showing, in addition to a high yield, larger diameter and length, corroborating Giles et al. (2016), who stated that a better pulp yield is associated with the selection of larger fruits.

The results obtained for fruit yield in the present study may be related to the size of the endocarp (kernel), as expressed in Table 3, and the fruit characteristics (epicarp and mesocarp) as the units from these regions (Queimadas and São Vicente do Seridó) showed a higher mass, length, fresh mass, and diameter. Chaves Neto and Silva (2019), in their study with the characterization of fruits of Spondias dulcis in different microregions of Paraíba, stated that higher pulp yields are related to a lower percentage of the endocarp. Commercial fruits 'B', even with an intermediate mean value for fruit parameters, showed the lowest endocarp mass and thickness as well as a small length (CS), similar to most studied endocarps. The same occurred for the diameter (DS) of this structure (Table 3). 
Table 3. Means of endocarp mass (ME), endocarp length (CE), endocarp width (LE), endocarp diameter (DE), and presence of hairs (PP) in fruits of Spondias tuberosa Arr. Câmara from semi-arid regions of Paraíba.

\begin{tabular}{cccccc}
\hline Municipality & $\mathrm{ME}(\mathrm{g})$ & $\mathrm{CE}(\mathrm{mm})$ & $\mathrm{LE}(\mathrm{mm})$ & $\mathrm{DE}(\mathrm{mm})$ & $\mathrm{PP}$ \\
\hline Boqueirão & $1.80 \mathrm{a}$ & $20.8 \mathrm{~b}$ & $14.6 \mathrm{~b}$ & $11.5 \mathrm{a}$ & $0.8 \mathrm{a}$ \\
Cabaceiras & $1.58 \mathrm{~b}$ & $20.2 \mathrm{~b}$ & $14.7 \mathrm{~b}$ & $11.5 \mathrm{a}$ & $0.6 \mathrm{~b}$ \\
Queimadas & $1.52 \mathrm{bc}$ & $22.4 \mathrm{a}$ & $15.5 \mathrm{a}$ & $11.9 \mathrm{a}$ & $0.8 \mathrm{a}$ \\
São Vicente do Seridó & $1.39 \mathrm{~cd}$ & $20.5 \mathrm{~b}$ & $13.3 \mathrm{c}$ & $10.6 \mathrm{~b}$ & $0.2 \mathrm{c}$ \\
Commercial A & $1.24 \mathrm{~cd}$ & $19.8 \mathrm{~b}$ & $14.1 \mathrm{~b}$ & $11.8 \mathrm{a}$ & $0.0 \mathrm{c}$ \\
Commercial B & $1.14 \mathrm{~d}$ & $20.3 \mathrm{~b}$ & $14.1 \mathrm{bc}$ & $11.4 \mathrm{a}$ & $0.0 \mathrm{c}$ \\
\hline
\end{tabular}

Means followed by the same letters in the column do not differ by the Tukey test at $5 \%$ probability. Commercial ' $\mathrm{A}$ ' $=$ Fruits from Pocinhos (PB) sold at the Arca Titão fair/Donwtown Campina Grande. Commercial 'B' = Fruits from Soledade (PB) sold at the Arca Catedral fair/ Donwtown Campina Grande.

Thus, this relationship between epicarp, mesocarp, and endocarp in umbu could possibly influence the consumer choice for certain fruits. Costa et al. (2015) stressed this when they stated that larger fruits are more attractive for fresh consumption. Moreover, this relationship also contributes to choosing fruits used to produce by-products by both the local population and the processing industry, in addition to their price and sale. Also, Santos et al. (2010) and Albuquerque (2002) highlighted that fruit quality among consumers is expressed by their size, color, taste, aroma, pulpy yield, and other fruit attributes.

For Freitas (2017), fruit quality is often attributed to the external appearance (size, shape, and peel color) and can be influenced and differ according to the different agricultural practices, genetic constitution, maturation stage, harvest season, and post-harvest treatment. Allied to that, Dutra et al. (2017) stressed that the best characters found in umbu fruits might also be related to the rainfall distribution of the growing location, which may have occurred in this study as the municipalities of Queimadas and São Vicente do Seridó showed the best rainfall rates (478.5 mm year-1 and $469.3 \mathrm{~mm}$ year-1, respectively) between January and December 2019, the period before the 2020 crop year (Figure 1).

Endocarp evaluation (Table 3) revealed that the length (CE), width (LE), and diameter (DE) of this structure were similar among most fruits from the studied regions and commercial ones; however, the fruits from Boqueirão showed the highest endocarp mass ( $\mathrm{ME}=1.80$ g).

According to Carvalho and Nakagawa (2000) and Popinigis (1977), larger seeds (endocarps) usually show better nutrition throughout their development and higher physiological quality, meaning well-formed embryos with more reserve substances and, consequently, more vigor. This can enable their use for seedling production both for orchard formation and the recovery of degraded areas in the northeastern semi-arid region.
It is noteworthy that, as well as fruits, the seeds from commercial units are below the regional mean values found for the studied parameters, which may justify their commercialization since, although smaller, they are still useful for fresh consumption, even though this could be considered a negative factor for industrial use.

When analyzing the presence and absence of hairs in umbu fruits, a genetic feature that gives the fruit a velvety appearance, $80 \%$ (a) of the samples from Queimadas and Boqueirão showed hairs in their peels, while $60 \%$ (b) of the fruits from Cabaceiras and $20 \%$ (c) from São Vicente showed hairs. None of the commercial fruits showed hairs (c). According to Saturnino et al. (1994), the variation in fruit mass and the variety of umbu pulps may be related to the different fruit shapes, their maturation, and peel pilosity.

Although the hairs in the fruits of some umbu genotypes are almost imperceptible and do not hinder their consumption, it is important to consider them since, in allergic processes, especially in children, this pilosity may unleash urticaria, atopic dermatitis, and oral allergy syndrome (SAO), for example. From this perspective, Sarinho and Lins (2017) stressed that fruits are among some food products responsible for allergic reactions due to characteristics such as the presence of hairs.

Therefore, pilosity in umbu fruits has to be considered for their commercialization, especially when their use is meant for the fresh consumption market.

After using the principal component analysis technique (CP), the individual results containing the respective eigenvectors, eigenvalues, and variance percentages are expressed in Table 4. The first two components obtained (CP1 and CP2) explained $84.6 \%$ of the total variance in the morphological characters and yield of the evaluated umbu fruits. Unlike this study, Chaves Neto et al. (2018), when developing a study with another species of the genus Spondia (Spondia dulcis Parkinson), used three principal components to explain $87.33 \%$ of the total variance in the data set referring to the bioactive compounds and antioxidant activity of ambarella fruits. 
Table 4. Eigenvalues, eigenvectors, correlation between the components and the original variables, percentage of the variance explained, and cumulative proportion (\%) based on ten characters of umbu fruits from municipalities of Paraíba.

\begin{tabular}{cccc}
\hline & \multicolumn{2}{c}{ Principal components $(\mathbf{C P})$} & \\
\cline { 2 - 3 } & $\mathbf{C P 1}$ & $\mathbf{C P 2}$ & Correlation \\
\hline CF & $\mathbf{0 . 3 8 1}$ & -0.225 & 0.933 \\
DF & $\mathbf{0 . 4 0 0}$ & -0.118 & 0.979 \\
MTF & $\mathbf{0 . 3 9 2}$ & -0.159 & 0.962 \\
MFF & $\mathbf{0 . 3 8 6}$ & -0.198 & 0.946 \\
CE & $\mathbf{0 . 3 6 5}$ & 0.021 & 0.895 \\
DE & 0.026 & 0.470 & - \\
LE & 0.257 & 0.391 & - \\
ME & 0.254 & 0.339 & - \\
RF & 0.077 & $\mathbf{- 0 . 5 3 2}$ & -0.837 \\
PP & $\mathbf{0 . 3 4}$ & 0.30 & 0.844 \\
Eigenvalues $(\lambda i)$ & $\mathbf{5 . 9 9 3}$ & $\mathbf{2 . 4 7 5}$ & - \\
Proportion (P) & 59.9 & 24.7 & - \\
C. Proportion (\%) & 59.9 & 84.7 & - \\
\hline
\end{tabular}

$\mathrm{CF}=$ Fruit length $; \mathrm{DF}=$ Fruit diameter $\mathrm{MTF}=$ Total fruit mass; $\mathrm{MFF}=$ Fresh fruit mass $\mathrm{CE}=$ Endocarp length; $\mathrm{DE}=\mathrm{Endocarp}$ diameter; $\mathrm{LE}=$ Endocarp width; $\mathrm{ME}=$ Endocarp mass; $\mathrm{RF}=$ Fruit yield; $\mathrm{PP}=$ Percentage of hairs.

The results of the present study agree with Rencher (2002), who emphasizes that the principal components considered should explain at least $70 \%$ of the total variance. Hongyu (2015) stressed that these components represented a linear combination of all original characteristics, in which the first two principal components concentrate most of the data variation in order for divergence can occur.
In this study, the first component (CP1) accounted for $59.9 \%$ of data variance, while the second (CP2) accounted for $24.7 \%$ of this variance. This result was similar to those obtained by Gondim et al. (2013) when developing a study on the fruit quality of yellow mombin accessions (Spondias sp.), whose total variance in the data set was mainly explained by CP1 (60.41\%) and CP2 $(14.4 \%)$.

Figure 2 showed that the first principal component represents a general index of fruit size (CF, DF, MTF MFF, $\mathrm{CE})$ and the percentage of hairs (PP), with the correlations between $\mathrm{CP} 1$ and the mentioned characters varying from 0.844 to 0.979 . On the other hand, the second principal component is related to fruit yield (RF), with $r=-0.837$.

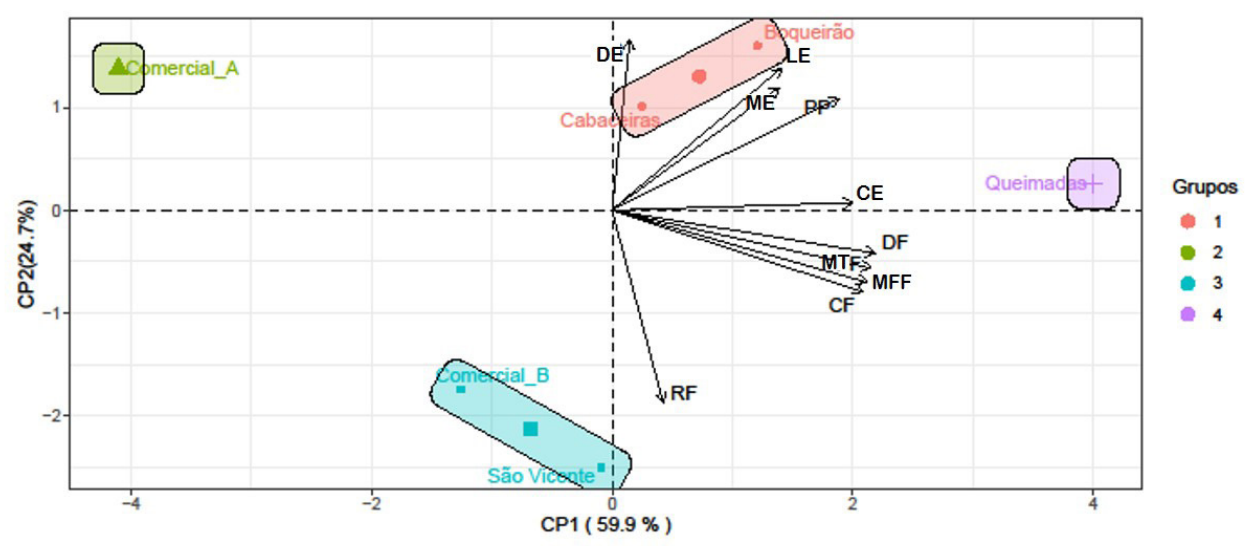

Figure 2. Dispersion of ten variables of umbu fruits from municipalities of Paraíba and cluster formation based on the scores of the first two principal components (CP1 and CP2). 
The cluster formed by fruits from Queimadas showed the highest score (values of variables) related to $\mathrm{CP} 1$, followed by the cluster formed by fruits from Boqueirão and Cabaceiras. On the other hand, the cluster with commercial fruits 'A' showed the lowest score in $\mathrm{CP} 1$, followed by the cluster formed by commercial fruits ' $\mathrm{B}$ ' and the cluster with fruits from São Vicente do Seridó.

Considering CP2, the cluster with the lowest fruit yield was formed by the samples from Boqueirão and Cabaceiras as well as commercial fruits ' $A$ '. In turn, the cluster formed by fruits from São Vicente do Seridó and commercial fruits ' $\mathrm{B}$ ' showed the highest fruit yield.

The cluster formed by fruits from the municipalities of Boqueirão and Cabaceiras (Cluster 1), and the one formed by fruits from São Vicente do Seridó and commercial fruits 'B' (Soledade) (Cluster 3) result from geographically close parent plants (Boqueirão - Cabaceiras $=17$ kilometers and São Vicente do Seridó - Soledade $=14$ kilometers) and may have been influenced by the similar local edaphoclimatic conditions (rainfall, type of soil, and temperature), resulting in the production of similar fruits. This corroborates the studies by Almeida et al. (2020) and Semensato et al. (2020), who observed that the edaphoclimatic conditions influenced fruit characteristics.

On the other hand, genetic factors may also have influenced these clusters. Since umbu is a species with a long life cycle, taking up to 12 years from seed germination to fruiting, techniques such as cutting or grafting are usually employed by umbu producers to obtain an early harvest. Therefore, this procedure may have contributed to the permutation and dissemination of related genotypes, with similar fruits in these close regions studied. According to Rocha et al. (2019), asexual propagation in Spondias ensures high productivity, fast fruiting, and planting homogeneity.

Therefore, the morphological characterization of umbu is an important strategy to preliminarily select promising genotypes for commercial fruit use as well as for biomolecular studies and the conservation of genetic resources of $S$. tuberosa Arruda Camara dispersed throughout the Caatinga of Paraíba, considering the socioeconomic and environmental value of the species.

Another hypothesis to be considered is related to seed dispersal in these areas as native animals, such as cotias (Dasyprocta cf. prymnolopha), collared peccaries (Tayassu tajacu), foxes (Dusicyon thous), six-banded armadillos (Euphractus sexcinctus), and brown brockets (Mazama gouazoubira) (BARRETO; CASTRO, 2010), in addition to goats (SENA; ALMEIDA, 2020) and cattle feed on these fruits, eliminating them in neighboring areas and favoring the gene flow and development of related plants in the studied municipalities.

Therefore, the molecular study of parent plants from the four municipalities, especially Queimadas and São Vicente do Seridó, whose fruits showed to be best suited for sale, along with the plant material from the municipality of Soledade, could contribute to assessing the genetic similarity and divergence between plants, leading to the production of fruits with similar characteristics (NEVES et al., 2019; MEIRA et al., 2020) and selecting other genotypes from these regions without hairs in their peel.

In addition to molecular biology studies, biochemical studies (total titratable acidity, total sugars, vitamin $\mathrm{C}$, and total soluble solids contents, expressed as ${ }^{\circ}$ Brix) should also be conducted in order to determine genotypes with the best fruit and seed morphological characters, in association with biochemical characteristics that would increasingly meet the demands of the national and international umbu markets both for fresh consumption and for the food processing or pharmaceutical industries, the latter meant for cosmetic production.

Regional strategies should also be used to foster the creation of cooperatives that promote the rational use of this natural resource in the municipalities of the semiarid region of Paraíba, generating jobs and income for the local population and contributing to the conservation of the species in the region.

\section{Conclusion}

The fruits from Queimadas and São Vicente do Seridó are the most promising for sale as they have the best morphological characters, while those from Boqueirão have the highest endocarp mass.

Most fruits had hairs in their peels, except the commercial ones.

Four clusters of municipalities were formed, with the fruits from Queimadas showing the largest size, while those from São Vicente de Seridó and Soledade showed the highest yields.

\section{References}

AESA - Agência Executiva de Gestão das Águas do Estado da Paraíba. Disponível em: http://www.aesa. pb.gov.br/aesa-website/meteorologia-chuvasgrafico/?id municipio $=154 \&$ date_chart $=2020-11-05 \&$ period=week. Acesso em: 05 nov. 2020.

ALBUQUERQUE, A.S.; BRUCKNER, C.H.; CRUZ, C.D.; CASALI, V.W.D.; ARAÚJO, R. C.; MOREIRA, A.E.; SOUZA, J.A. Possibilidade de seleção indireta para massa do fruto e rendimento em polpa em maracujá (Passiflora edulis Sims). In: CONGRESSO BRASILEIRO DE FRUTICUlTURA, 17., 2002, Belém. Anais [...]. Belém: Embrapa, 2002. CD-ROOM. 
ALCÂNTARA, L.K.S.; MACHADO, L.F.C.; CERAVOLO, I.P.; SANTOS, R.M.; DIAS-SOUZA, M.V. Phytochemical aspects, cytotoxicity and antimicrobial activity of the methanolic extract of tropical fruit pulps on clinical isolates of Escherichia coli. Biointerface Research in Applied Chemistry, Romania, v. 11, n. 1, p. $8210-8217,2021$.

ALMEIDA, S.R.; MEDEIROS, E.; SOUZA, L.D.; ARAÚJO, L.A.; OLIVEIRA, L.N.; NUNES, G.L. Efeito do processo de secagem sobre as características nutricionais de cajá-manga (Spondias mombin L.). Revista Referências em Saúde da Faculdade Estácio de Sá de Goiás RRS-FESGO, Goiânia, v.3, n.2, p.33-36, 2020.

ALVES, T.P.; SILVA, R.A.C.; SANTOS, S.; SILVA, J.C.S. Qualidade pós-colheita de frutos do umbuzeiro (Spondias tuberosa Arruda) armazenados sob atmosfera modificada. Diversitas Journal, Arapiraca, v.5, n.3, p.1523-1535, 2020.

ARAÚJO, E.J.S.; SANTOS, J.A.B.; NARAIN, N. Avaliação da influência de diferentes condições de liofilização nas características físico químicas e sensoriais do umbu em pó. Brazilian Journal of Development, Curitiba, v. 6, n. 9, 2020.

ASSIS, R.C.; SOARES, R.L.G.; SIQUEIRA, A.C.P.; ROSSO, V.V.; SOUSA, P.H.M.; MENDES, A.E.P.; COSTA, E.A.; CARNEIRO, A.P.G.; MAIA, C.S.C. Determination of water-soluble vitamins and carotenoids in Brazilian tropical fruits by high performance liquid chromatography. Heliyon, London, v.6, p.1-10, 2020.

BARRETO, L.S.; CASTRO, M.S. Boas práticas de manejo para o extrativismo sustentável do umbu. Brasília: Embrapa Recursos Genéticos e Biotecnologia, 2010. 64 p.

BATISTA, F.R.C.; SILVA, S.M.; M. SANTANA, F.S.; CAVALCANTE, A.R. O umbuzeiro e o semiárido brasileiro. Campina Grande: INSA, 2015. 72 p.

CARVALHO, C.; KIST, B.B.; BELING, R.R. Anuário brasileiro de horti\&fruti 2020. Santa Cruz do Sul: Editora Gazeta Santa Cruz, 2019. 96 p.

CARVALHO, N.M.; NAKAGAWA, J. Sementes: ciência tecnologia e produção. 4.ed. Jaboticabal: FUNEP, 2000. $588 \mathrm{p}$.
CASTRO, C.D.P.C.; RYBKA, A.C.P. Potencialidades do fruto do umbuzeiro para a agroindústria de alimentos. Petrolina: Embrapa Semiárido, 2015. 19 p. (Documento, 270).

CASTRO, C.D.P.C.; RYBKA, A.C.P. Processamento de doce de umbu com amêndoas de licuri. Petrolina: Embrapa Semiárido, 2020. 7p. (Comunicado técnico, 175).

CHAVES NETO, J.R.; SILVA, S.M. Caracterização física e físico-química de frutos de Spondias dulcis Parkinson de diferentes microrregiões do Estado da Paraíba. Colloquium Agrariae, Presidente Prudente, v. 15, n.2, p. 18-28, 2019.

CHAVES NETO, J.R.; ANDRADE, M. DAS G.S.; SCHUNEMANN, A.P.P.; SILVA, S.M. Compostos fenólicos, carotenoides e atividade antioxidante em frutos de cajá-manga. Boletim do Centro de Pesquisa de Processamento de Alimentos, Curitiba, v.36, n.1, 2018.

CONCEIÇÃO, H.B.S.; MELO, C.S.; FERREIRA, I.M.; SILVA, A.M.O.; CARVALHO, M.G. Sorvete de umbu e mangaba: vida de prateleira e viabilidade do Bacillus clausii. Brazilian Journal of Hygiene and Animal Sanity, Fortaleza, v.14, n.1, p.53-66, 2020.

CONCEIÇÃO, M.J.F.; BARROS, R.P. Biometrics of fruits and seeds sold in open markets. Revista da Universidade Estadual de Alagoas, Arapiraca, v.12, n. 3, p.16-31, 2020 .

CORDEIRO, B.M.P.C.; CARVALHO JUNIOR, A.R.; SANTOS, J.R.A.; ARAUJO A.D.; SILVA, A.G.; CORREIA, M.T.S.; SILVA, M.V.; NAPOLEÃO T.H.; SILVA, L.C.N.; SANTOS, N.D.L.; PAIVA, P.M.G. Anticryptococcal activity of hexane extract from Spondias tuberosa Arruda and associated cellular events. Journal de Mycologie Medicale, Amsterdam, v.30, p.1-5, 2020.

COSTA, F.R.; RÊGO, E.R.; RÊGO, M.M.; NEDER, D.G.; SILVA, S.M.; SCHUNEMANN, A. P.P. Análise biométrica de frutos de umbuzeiro do semiárido brasileiro. Bioscience Journal, Uberlândia, v.31, n.3, p.682-690. 2015.

COSTA, F.R.B.; SILVA, M.M.A.; ARAÚJO, V.S. Uso sustentável do umbuzeiro: estratégia de convivência com o semiárido. Campina Grande: INSA, 2015. 15p. 
DUTRA, F.V.; CARDOSO, A.D.; MORAIS, O.M.; VIANA, A.E.S.; MELO, T.L.; CARDOSO JÚNIOR, N.S. Características físicas e químicas de acessos de umbuzeiros (Spondias tuberosa Arr. Cam). Revista de Ciências Agrárias, Fortaleza, v.40, n. 4, p.814-822, 2017.

FAO - Food and Agriculture Organization of the United Nations. The state of food insecurity in the world. Rome: FAO, 2010.57p.

FRANÇA, K.M.A.; ROCHA, L.F.C.S.; SOUSA, L.F.C.; MELO, R.S.S.; DANTAS, A.C.A. Caracterização morfológica de cajuí (Anacardium sp.) do Cerrado Sul Maranhense. Acta Tecnológica, São Luis, v.14, n.1, p.79-91, 2019.

FRANCISCO P.R.M.; MEDEIROS, R.M.; MELO,V.S. Estudo agroclimático do município de Cabaceiras-PB. Campina Grande-PB: EDUFCG, 2016. v.1, 158p.

FRANCISCO, P.R.M.; MEDEIROS, R.M.; SANTOS, D. Balanço hídrico climatológico para a capacidade de campo de 100 mm - Estado da Paraíba. Campina Grande: EDUFCG, 2018. v.1, 257p.

FRANCISCO, P.R.M.; SANTOS, D. Climatologia do Estado da Paraíba. Campina Grande: EDUFCG, 2017. v. $1,75 p$.

FREITAS, B.S.M. Caracterização e qualidade física e química dos frutos e secagem por leito de espuma da polpa de cajá (Spondias mombin L.). 2017. Dissertação (Mestrado em Tecnologia de Alimentos - Instituto Federal de Educação, Ciências e Tecnologia Goiano, Campus Rio Verde. Rio Verde, Goiás, 2017.

GILES, J.A.D.; OLIARI, L.S.; ROCHA, A.C.B.; SCHMILDT, E.R.; SILVA, W.; FRANÇA, J.M. Correlações entre características físicas, químicas e físico-químicas de frutos de cirigueleira. Revista Agro@mbiente On-line, v.10, n.1, p.30-35, 2016.

GOMES, D.L.; SILVA, A.P.L.; ARAUJO, K.D.; LIRA, E.S.; SANTOS, E.M.C.; COSTA, J.G. Exploração da caatinga em assentamentos rurais do semiárido alagoano. Revista Espaço Geográfico em Análise, Curitiba, v.45, p.142 -152. 2018.
GONDIM, P.J.S.; SILVA, S.M.; PEREIRA, W.E.; DANTAS, A.L.; CHAVES NETO, J.R.; SANTOS, L.F. Qualidade de frutos de acessos de umbu-cajazeira (Spondias sp.). Revista Brasileira de Engenharia Agrícola e Ambiental, Campina Grande, v.17, n.11, p.1217-1221, 2013.

HONGYU, K. Comparação do GGEbiplot ponderado e AMMI-ponderado com outros modelos de interação genótipo $\times$ ambiente. 2015. Tese (Doutorado em Estatística e Experimentação Agronômica) - Escola Superior de Agricultura “Luiz de Queiroz”, Universidade de São Paulo, Piracicaba, 2015.

IBRAF. Instituto Brasileiro de Frutas. Frutas frescas importação. Comparativo de importações e exportações. São Paulo, 2017. 96p.

LIMA JUNIOR, L.C.; DIAS S.S.; SIMAS, L. Alimentos funcionais na prevenção e tratamento de doenças crônicas não transmissíveis. Boletim de Conjuntura, Boa Vista, v.4, n.10, 2020.

LIMA, M.S.S.; DANTAS, A.C.V.L.; FONSECA, A.A.O.; BARROSO, J.P. Caracterização de frutos de genótipos selecionados de umbu-cajazeira (Spondias sp.). Interciencia, Caracas, v.40, n.5, p. 311-316, 2015.

LORENZI, H.; LACERDA, M.T.C.; BACHER, L.B. Frutas no Brasil nativas e exóticas: de consumo in natura. São Paulo: Instituto Plantarum de Estudos da Flora, 2015.

MARQUES, E.J.N.; FREITAS, S.T. Performance of new low-cost handheld NIR spectrometers for nondestructive analysis of umbu (Spondias tuberosa Arruda) quality. Food Chemistry, London, v. 323, p.1-10, 2020.

MATOS, F.S.; FREITAS, I.A.S.; PEREIRA, V.L.G.; PIRES, W.K.L. Effect of gibberellin on growth and development of Spondias tuberosa seedlings. Revista Caatinga, Mossoró, v.33, n.4, p.1124 - 1130, 2020.

MEIRA, M. R.; SANTOS, L.H.T.; ANJOS, Q.Q.A.; SANTOS, B.E.F.; GUIMARÃES, L.S.; SILVA, C.B.M.C. Caracterização molecular de Prosopis juliflora (Sw.) DC. por meio de marcadores moleculares e índices de similaridade genética. Biotemas, Florianópolis, v.33, n.1, p.1-9, 2020. 
MENEZES, P.H.S. Influência do estádio de maturação na qualidade físico química de frutos de umbu (Spondias tuberosa). Scientia Agropecuaria, Trujillo, v.8, n.1, p.73-78, 2017.

PÁDUA, J.G.; ALBUQUERQUE, M.S.M.; MELLO, S.C.M. Bancos e coleções de germoplasma da Embrapa: conservação e uso. Brasília, DF: Embrapa Recursos Genéticos e Biotecnologia, 2020. 167 p. (Documentos, 371).

PAODJUENAS R.; COSTA, G.M.; NUNES, E.N.; PAULINO, F.O.; LUCENA, R.F.P. Conhecimento tradicional e usos do umbuzeiro (Spondias tuberosa Arruda) por comunidades rurais do semiárido, Paraíba, nordeste, Brasil. Ethnoscientia, Botucatu, v.4, 2019.

POPINIGIS, F. Fisiologia da semente. Brasília, DF: AGIPLAN, 1977. 289 p.

RENCHER, A.C. Methods of multivariate analysis. London: John Wiley \& Sons, 2002. p.727.

RIBEIRO, J.S.; SILVA, L.K.R.; NEVES, O.S.C.; TAPIA, D.M.T.; CARDOSO, L.G.V.; PEREIRA, M.A.R.S. Desenvolvimento e análise sensorial de leite saborizado com polpa de umbu (Spondias tuberosa Arr. Câm.). Revista Brasileira de Produtos Agroindustriais, Campina Grande, v.19, n.3, p.255-260, 2017.

RIBEIRO, L.O.; PONTES, S.M.; RIBEIRO, A.P.O., PACHECO, S.; FREITAS S.P.; MATTA, V.M. Avaliação do armazenamento a frio sobre os compostos bioativos e as características físico-químicas e microbiológicas do suco de umbu pasteurizado. Brazilian Journal of Food Technology, São Paulo, v. 20, p.8, 2017.

ROCHA, G.T.; SILVA, A.G.; PEIXOTO, N.; MARTINS, J.B.; RODRIGUES, F. Vegetative propagation of red mombin (Spondias purpurea) with immersion in indole3-acetic acid. Revista Brasileira de Ciências Agrárias, Recife, v.14, n.2, 2019.

SANTOS, C.A.F. Dispersão da variabilidade genética do umbuzeiro no semi-árido brasileiro. Pesquisa Agropecuária Brasileira, Brasília, DF, v. 32, n. 6, p. 923-930, 1997.
SANTOS, L.J.S.; ARANTES, A.M.; DONATO, S.L.R.; BRITO, C.F.B.; LIMA, M.A.C.; RODRIGUES FILHO, V.A. Leaf contents and biochemical cycing of nutrients in accessions of umbu and umbu-caja. Revista Caatinga, Mossoró, v.33, n.3, p. 690-701, 2020.

SANTOS, M.B; CARDOSO, R.L.; FONSECA, A.A. OLIVEIRA; CONCEICAO, M.N. Caracterização e qualidade de frutos de umbu-cajá (Spondias tuberosa X $S$. mombin) provenientes do recôncavo sul da Bahia. Revista Brasileira de Fruticultura, Jaboticabal, v.32, n.4, p.1089-1097, 2010.

SANTOS, V.; ALMEIDA, C. The complete chloroplast genome sequences of three Spondias species reveal close relationship among the species. Genetics and Molecular Biology, Ribeirão Preto, v.42, n.1, p.132-138, 2019.

SARINHO, E.; LINS M.G. Severe forms of food allergy. Jornal de Pediatria, São Paulo, v.93, s.1, p.53-59, 2017.

SATURNINO, H.M.; OLIVEIRA, C.L.G.; CAETANO, F.S. Culturas tradicionais e plantas úteis da região da Caatinga de Minas Gerais. Informe Agropecuário, Belo Horizonte, v.17, n.18, p.86-93, 1994.

SEMENSATO, L.R.; VENDRUSCOLO, E.P.; SELEGUINI, A.; BATISTA FILHO, P.A.; SILVA, E.C.M.; SILVA, T.P. Fenologia, produtividade e qualidade de frutos de jabuticabeiras de diferentes idades das plantas. Iheringia, São Paulo, v.75, p.9, 2020.

SENA, F.H.; ALMEIDA, J.S. Avaliação da germinação de sementes de Spondias tuberosa Arr. dispersas por caprinos. Journal of Environmental Analysis and Progress, Recife, v.5, n.2, p.186-193, 2020.

SILVA, S.A.; DANTAS, A.C.V.L.; COSTA, M.A.P.C.; FERREIRA, C.F.; FONSECA, A.A.O. Caracterização de genótipos de fruteiras potenciais para o Nordeste Brasileiro. In: Tópicos em Ciências Agrárias. Curitiba: Editora Poisson, 2009. 296 p.

SILVA, M.A.A.; NASCIMENTO, F.A.O.; DINIZ, M.C. Technologies mapping using the gender Spondias (Anacarddeaceae) in the last 20 years. Revista INGI, Petrolina, v.2, n.2, p.96-108. 2018. 
SILVA, V.P.; PAZ, M.A.; SOUSA, K.S.M.; ABREU, A.K.F. Qualidade pós-colheita de frutos de umbuzeiro (Spondias tuberosa Arr.) embalados com filme de PVC. Revista Craibeiras de Agroecologia, Rio Largo, v.4, n. 1, 2019.

TAVARES, F.J.C.; ALVES, R.E.; LUCENA, E.M.P. Compilation of nutritional composition data of fruits of six species of Myrtaceae natives of Brazil according to FAO/INFOODS methodology. Brazilian Journal of Development, Curitiba, v.6, n.8, p.63712-63728, 2020.
TEIXEIRA, E.T.A. Análise biométrica e físico-química de frutos de umbu-cajá Spondia tuberosa x Spondia mobin. In: CONGRESSO DE INICIAÇÃO CIENTÍFICA DA FASB, 17., 2019, Barreiras. Anais [...]. Barreiras: Faculdade São Francisco de Barreiras, 2019.

WILLETT, W.C. Diet and health: what should we eat? Science, London, v.254, p.532-537, 1994. 